\title{
Studi Deskriptif Tingkat Kecemasan Pada Wanita Klimakterium di Wilayah Kerja Puskesmas Prabumulih Barat
}

\section{Intan Sari}

Akademi Kebidanan Budi Mulia Prabumulih

\section{Informasi Artikel :}

Diterima : 28 April 2020

Direvisi : 04 Mei 2020

Disetujui : 18 Mei 2020

*Korespondensi Penulis : Intannadhifa215S@gmail.com

\section{A B S T R A K}

Kecemasan adalah manifestasi dari berbagai proses emosi yang bercampur aduk yang terjadi ketika orang mengalami tekanan perasaan dan pertentangan batin atau konflik. ${ }^{1}$ Seorang wanita pada masa klimakterium bisa mengalami kecemasan. Saat masuknya seseorang dalam masa klimakterium sangat berbeda - beda. Penelitian ini bertujuan untuk mengetahui tingkat kecemasa pada masa klimakterium di Wilayah Kerja Puskesmas Prabumulih Barat. Penelitian ini menggunakan metode deskriptif yang menggambarkan tingkat kecemasan pada wanita klimakterium. Rancangan yang digunakan adalah survey cross sectional dengan pendekatan, observasi, atau pengumpulan data sekaligus pada suatu saat. ${ }^{8}$ Populasi dalam penelitian ini adalah seluruh wanita klimakterium usia 45-55 tahun di Wilayah Kerja Puskesmas Prabumulih Barat 2020, sebanyak 250 orang. Menurut Arikunto,2005 jika jumlah populasinya besar (>100) dapat diambil antara $10-15 \%$, atau $20-25 \%$ atau lebih ${ }^{9}$ Dalam penelitian ini peneliti mengambil sampel sebanyak $20 \%$ dari seluruh populasi yaitu 50 orang. Dari hasil penelitian diketahui bahwa tingkat kecemasan wanita klimakterium di Wilayah Kerja Puskesmas Prabumulih Barat dapat disimpulkan, Karakteristik data dari 50 responden mayoritas berpendidikan SD sebanyak 32 orang (64\%) yang sebagian besar bekerja sebagai petani sebanyak 23 orang (46\%) dengan pendapatan antara Rp 650.000 - Rp 1.000.000 sebanyak 40 orang (80\%) dan mayoritas memiliki anak lebih dari 3 orang. Tingkat kecemasan dari data mayoritas wanita mengalami kecemasan sedang sebanyak 22 orang (44\%). Diharapkan dengan adanya penelitian ini dapat membantu para wanita siap dalam menghadapi masa klimakterium.

\section{Kata Kunci : Masa antara, Kecemasan, Klimakterium}

\section{ABSTRACT}

Anxiety is a manifestation of various mixed emotional processes that occur when people experience emotional distress and conflict or conflict.1 A woman in climacteric times can experience anxiety. When a person enters the climacterium period is very different different. This study aims to determine the level of anxiety in the climacteric period in the Work Area of the West Prabumulih Health Center. This study uses descriptive methods that describe the level of anxiety in climacteric women. The design used was a cross sectional survey with approach, observation, or data collection at one time. 8 The population in this study were all climacteric women aged 45-55 years in the Work Area of the West Prabumulih Health Center in 2020, totaling 250 people. According to Arikunto, 2005 if a large population (> 100) can be taken between 10-15\%, or 20- 
$25 \%$ or more. 9 In this study the researchers took a sample of $20 \%$ of the total population of 50 people. From the research results it is known that the anxiety level of climacteric women in the Prabumulih Barat Public Health Center Work Area can be concluded. Data characteristics of the majority of respondents are 32 elementary school graduates (64\%), mostly working as farmers as many as 23 people (46\%) with income between $R p .650,000-R p$ 1,000,000 of 40 people (80\%) and the majority have more than 3 children. Anxiety level from the data the majority of women experience moderate anxiety as many as 22 people (44\%). It is hoped that this research can help women be ready to face the climacteric period.

Keywords: Intermediate, Anxiety, Climacterium

\section{PENDAHULUAN}

Kecemasan adalah manifestasi dari berbagai proses emosi yang bercampur aduk yang terjadi ketika orang mengalami tekanan perasaan dan pertentangan batin atau konflik. ${ }^{1}$ Seorang wanita pada masa klimakterium bisa mengalami kecemasan. Pada wanita klimkterium, kadar serotin (salah satu bentuk transmitter) mengalami penurunan sebagai akibat dari jumlah estrogen yang minim. Fungsi dari serotinin adalah berperan dalam mempengaruhi suasana hati seseorang, bila jumlah serotonin berkurang akan mengakibatkan orang tersebut sukar tidur. Disamping itu penurunan hormone menyebabkan rasa cemas yang tidak beralasan karena reseptor estrogen yang terdapat dalam otak (amigdala) berespon terhadap penurunan kadar hormon estrogen. Reseptor ini menciptakan rasa sejahtera, meningkatkan gairah seksual, dengan adanya penurunan maka fungsi normalnya juga berkurang. Sehingga wanita klimakterium kurang merasa sejahtera, sehingga timbul rasa cemas. Namun perasaan cemas ini tidak selalu sama antara wanita yang mengalami klimakterium, tergantung dari tekanan hidupnya. ${ }^{2}$

Menurut badan statistik pada tahun 20052015 jumlah perempuan Indonesia diatas usia 50 tahun adalah 15,9 juta orang, dan pada tahun 2025 diperkirakan akan ada 60 juta perempuan masa klimakterium. ${ }^{2}$ Sumatera Selatan dengan jumlah penduduk mencapai 35 juta, dari jumlah tersebut sekitar $60 \%$ nya adalah perempuan, dan jumlah wanita klimakterium di sekitar 1,5 juta orang. ${ }^{3}$ Sedangkan di Kota Prabumulih pada tahun 2017 terdapat 45.097 (4,5\%) orang wanita memasuki masa klimakterum (DKK Prabumulih, 2017). Di Wilayah kerja Puskesmas Prabumulih
Barat sendiri terdapat 50 orang wanita klimakterium. Dengan perhitungan usia harapan hidup wanita 70 tahun, jadi seorang wanita akan menjalani waktu 5 sampai 6 tahun dalam masa klimakterium. $^{4}$

Saat masuknya seseorang dalam masa klimakterium sangat berbeda - beda, wanita Eropa tidak sama usia klimakteriumnya dengan wanita Asia. Faktor genetik kemungkinan berperan terhadap usia klimakterium. Baik usia pertama haid (menarche), melahirkan pada usia muda, maupun berat badan tidak terbukti mempercepat datangnya menopause. Memasuki usia klimakterium lebih awal dijumpai pada wanita nullipara, wanita dengan Diabetes Mellitus (penyakit gula), perokok berat, kurang gizi, wanita vegetarian, wanita dengan sosioekonomi rendah, dan wanita yang banyak mengkonsumsi daging, dan minum alkohol akan mengalami gejala klimakterium lebih lambat. ${ }^{5}$

Masa klimakterium sebenarnya hanyalah sebuah tahap transisi yang harus dilalui setiap perempuan dan merupakan tahap akhir proses biologi yang dialami wanita berupa penurunan produksi hormon. Gejala klimakterium merupakan pengalaman individual. Dimana perubahan dan gangguan pada seluruh jaringan tubuh, untuk masing-masing wanita berbeda-beda dari yang ringan sampai yang berat. ${ }^{6}$

Adapun gejala fisik yang terjadi pada wanita klimakterium juga sangat penting dalam kehidupan sosial wanita. Berbicara tentang aspek fisik wanita klimakterium dalam pendekatan efektif holistik, sebenarnya tidak dapat dipisahkan antara organ biologis, psikologis, social budaya, dan spiritual dalam kehidupan wanita klimakterium, gejala yang menonjol mengakibatkan wanita tersebut mengalami kecemasan antara lain : ketidakteraturan siklus 
haid, gejolak rasa panas(hot flashes), perubahan kulit, keringat di malam hari, badan menjadi gemuk dan kerapuhan tulang. Hal ini mempengaruhi aspek psikologis wanita klimakterium sehingga dapat juga menimbulkan kecemasan, misalnya mudah tersinggung, sukar tidur, tertekan, gugup, kesepian, tidak sabar, tegang, cemas dan depresi. Kecemasan dari ibuibu yang telah menopause umumnya bersifat relatif, artinya ada orang yang cemas dan dapat tenang kembali, setelah mendapat semangat atau dukungan dari orang sekitarnya, namun ada juga yang terus-menerus cemas, meskipun orangorang sekitarnya memberi dukungan. Akan tetapi banyak juga ibu-ibu yang mengalami menopause namun tidak mengalami perubahan yang berarti dalam kehidupannya. ${ }^{7}$

Berdasarkan survey pendahuluan yang dilakukan di Wilayah Kerja Puskesmas Prabumulih Batat terhadap 7 orang wanita yang memasuki masa klimakterium usia 45-55 tahun Yang mengalami gangguan menstruasi sebanyak 4 wanita $\pm(8 \%)$. Dalam keadaan ini ibu merasa takut terjadi kehamilan karena menstruasinya terlambat takut pada penyakit karena menstruasinya sedikit-sedikit, takut berhubungan seksual takut suami selingkuh, takut kulit mengendor, dan takut menjadi tua.

Berdasarkan pernyataan di atas, penulis tertarik untuk melakukan penelitian dengan judul tingkat kecemasan pada wanita klimakterium yang dilaksanakan di Wilayah Kerja Puskesmas Prabumulih Barat.

\section{METODE PENELITIAN}

Penelitian ini menggunakan metode deskriptif yang menggambarkan tingkat kecemasan pada wanita klimakterium. Rancangan yang digunakan adalah survey cross sectional dengan pendekatan, observasi, atau pengumpulan data sekaligus pada suatu saat. ${ }^{8}$ Populasi dalam penelitian ini adalah seluruh wanita klimakterium usia 45-55 tahun di Wilayah Kerja Puskesmas Prabumulih Barat 2020, sebanyak 250 orang. Menurut Arikunto,2005 jika jumlah populasinya besar (>100) dapat diambil antara $10-15 \%$, atau $20-25 \%$ atau lebih ${ }^{9}$ Dalam penelitian ini peneliti mengambil sampel sebanyak $20 \%$ dari seluruh populasi yaitu 50 orang. Tempat penelitian ini dilakukan di Wilayah Kerja Puskesmas Prabumulih Barat. Data yang telah diolah kemudian dianalisa dengan menggunakan analisa univariat. Dalam hal ini pengolahan data dengan menggambarkan dan meringkas data secara alamiah dalam bentuk tabel atau grafik.

\section{HASIL PENELITIAN}

\section{Karakteristik ibu}

Hasil penelitian tentang karakteristik ibu yang meliputi pendidikan, pekerjaan, pendapatan, jumlah anak adalah sebagai berikut :

a. Distribusi responden berdasarkan tingkat pendidikan

Tabel 1 Distribusi responden berdasarkan pendidikan di Wilayah Kerja Puskesmas Prabumulih Barat

\begin{tabular}{lcc}
\hline \multicolumn{1}{c}{ Pendidikan } & Jumlah & Persentase ( \%) \\
\hline Tidak tamat SD & 5 & 10 \\
SD & 32 & 64 \\
SMP & 7 & 14 \\
SMA & 2 & 4 \\
S1/DIII & 4 & 8 \\
\hline \multicolumn{1}{c}{ Total } & 50 & 100 \\
\hline \multicolumn{2}{c}{ Berdasarkan }
\end{tabular}

penelitian menunjukkan bahwa dari 50 responden mayoritas berpendidikan SD yaitu 32 orang $(64 \%)$ selanjutnya berpendidikan SMP sebanyak 7 orang (14\%), tidak tamat SD sebanyak 5 orang $(10 \%)$ berpendidikan S1/Diploma sebanyak 4 orang (8\%) sedangkan berpendidikan SMA paling sedikit yaitu 2 orang (4\%).

b. Distribusi responden berdasarkan pekerjaan

Tabel 2 Distribusi Responden Berdasarkan Pekerjaan Ibu di Wilayah Kerja Puskesmas Prabumulih Barat.

\begin{tabular}{ccc}
\hline Pekerjaan & Jumlah & Prosentase (\%) \\
\hline Petani & 23 & 46 \\
Swasta & 15 & 30 \\
Buruh & 8 & 16 \\
PNS & 4 & 8 \\
\hline total & 50 & 100 \\
\hline
\end{tabular}

Berdasarkan tabel di atas, hasil penelitian menunjukkan bahwa dari 50 orang responden mayoritas bekerja sebagai petani sebanyak 23 orang (46\%) sedangkan sebanyak 15 orang $(30 \%)$ bekerja sebagai wiraswasta, sebanyak 8 orang $(16 \%)$ bekerja sebagai buruh dan yang paling sedikit yaitu sebanyak 4 orang $(8 \%)$ bekerja sebagai PNS. 
c. Distribusi responden berdasarkan
pendapatan

Tabel 3 Distribusi Responden Berdasarkan Pendapatan Ibu di Wilayah Kerja Puskesmas Prabumulih Barat.

\begin{tabular}{ccc}
\hline Pendapatan & Jumlah & $\begin{array}{c}\text { Prosentase } \\
(\mathbf{\%})\end{array}$ \\
\hline$<\mathrm{Rp} \mathrm{650.000}$ & 20 & 40 \\
$\mathrm{Rp} \mathrm{650.000-}$ & 20 & 40 \\
$\mathrm{Rp} \mathrm{1} \mathrm{juta}$ & 10 & 20 \\
$>\mathrm{Rp} \mathrm{1.} \mathrm{000.}$ & & \\
000 & & 100 \\
\hline Total & 50 & \\
\hline
\end{tabular}

Berdasarkan tabel di atas, hasil penelitian menunjukkan bahwa yang mempunyai penghasilan $<\operatorname{Rp} 650.000$ dan Rp 650.000- Rp 1.000.000 adalah sama sebanyak masing-masing 20 orang (40\%) sedangkan sebanyak 10 orang $(20 \%)$ mempunyai penghasilan sebanyak $\mathrm{Rp}>1$. 000. 000 .

d. Distribusi responden berdasarkan jumlah anak

Tabel 4. Distribusi Responden Berdasarkan Jumlah Anak di Wilayah Kerja Puskesmas Prabumulih Barat.

\begin{tabular}{ccc}
\hline Jumlah Anak & Jumlah & $\begin{array}{c}\text { Prosentase } \\
(\mathbf{\%})\end{array}$ \\
\hline Jumlah anak 0 & 0 & 0 \\
Jumlah anak 1 & 4 & 8 \\
Jumlah anak 2 & 11 & 22 \\
Jumlah anak 3 & 15 & 30 \\
Jumlah anak >3 & 20 & 40 \\
\hline \multicolumn{1}{c}{ Total } & 50 & 100 \\
\hline
\end{tabular}

Dari tabel di atas, hasil penelitian menunjukkan bahwa dari 50 responden. Paling banyak mempunyai anak >3 yaitu sebanyak 20 orang $(40 \%)$ selanjutnya yang mempunyai 3 orang anak sebanyak 15 responden $(30 \%), 11$ orang mempunyai 2 orang anak (22\%) dan yang paling sedikit mempunyai 1 orang anak sebanyak 4 responden $(8 \%)$.

\section{Tingkat kecemasan}

Tabel 5 Distribusi Responden Berdasarkan Tingkat Kecemaasan Ibu di Wilayah Kerja Puskesmas Prabumulih Barat.

\begin{tabular}{lcc}
\hline Tingkat kecemasan & Jumlah & $\begin{array}{c}\text { Prosentase } \\
(\mathbf{\%})\end{array}$ \\
\hline Tidak ada kecemasan & 3 & 6 \\
Kecemasan ringan & 21 & 42 \\
Kecemasan sedang & 22 & 44 \\
Kecemasan berat & 4 & 8 \\
\hline \multicolumn{1}{c}{ Total } & 50 & 100 \\
\hline
\end{tabular}

Dari tabel 5 didapatkan hasil bahwa dari 50 orng responden yang paling banyak mengalami kecemasan sedang yaitu sebanyak 22 orang (44\%), mengalami kecemasan ringan sebanyak 21 orang $(42 \%)$ dan kecemasan berat sebanyak 4 orang (8\%), yang paling sedikit tidak mengalami kecemasan sebanyak 3 orang $(6 \%)$.

\section{PEMBAHASAN}

Pada bagian ini akan dibahas penelitian yang meliputi karakteristik responden yang berkaitan dengan pendidikan, pekerjaan, pendapatan, jumlah anak serta tingkat kecemasan wanita klimakterium usia 45-55 tahun di Wilayah Kerja Puskesmas Prabumulih Barat dan selanjutnnya menganalisa hasil tersebut berdasarkan tinjauan teori.

Hasil penelitian menunujukkan bahwa wanita klimakterium di Wilayah Kerja Puskesmas Prabumulih Barat sebagian besar mengalami kecemaasan sedang. Kecemasan merupakan manifestasi dari berbagai proses emosi yang bercampur aduk yang terjadi ketika seseorang mengalami kekacauan perasaan dan pertentangan batin atau konflik. ${ }^{10}$ Tingkat kecemasan dapat dipengaruhi oleh berbagai faktor diantaranya pendidikan, dari hasil penelitian mayoritas responden berpendidikan SD. Tingkat pendidikan dasar merupakan tingkat pendidikan yang paling rendah, sehingga pendidikan berhubungan dengan pengetahuan, perilaku dalam menghadapi masalah yang berkaitan dengan kecemasan masa klimakterium. 11 Dari bahasan tersebut dapat diambil kesimpulan bahwa semakin tinggi tingkat pendidikan akan semakin baik seseorang dalam mengatasi dan memecahkan suatu persoalan utamanya yang berkaitan dengan kecemasan masa klimakterium.

Faktor pekerjaan dan pendapatan juga berpengaruh terhadap tingkat kecemasan, mayoritas responden tidak hanya sebagai ibu rumah tangga tetapi juga bekerja sebagai petani yang mempunyai pendapatan rata-rata menengah kebawah. Dengan adanya pendapatan kurang wanita tersebut merasa tertekan dan 
cemas karena kurang bisa memenuhi kebutuhan. Semakin pendapannya cukup maka seseorang akan semakin memperhatikan status kesehatannya, karena ada sarana untuk memeriksakan kesehatan sehingga dapat meningkatkan kwalitas hidupnya. ${ }^{12}$

Dari bahasan diatas dapat disimpulkan bahwa semakin cukup pendapatannya, wanita tersebut cenderung bisa meningkatkan kwalitas hidupnya sehingga semakin berkurang kecemasan yang dialami wanita klimakterium tersebut.

Jumlah anak juga dapat menjadi faktor terjadinya kecemasan. Dari 50 responden mayoritas mempunyai anak lebih dari 3. Hasil tersebut menunjukkan bahwa sebagian besar wanita klimakterium di Wilayah Kerja Puskesmas Prabumulih Barat hanya terfokus dengan urusan anak dan jika dikaitkan dengan kecemasan yang dialami wanita klimakterium tersebut, mereka sibuk mengurus anak-anaknya, memikirkan tentang pendidikannya dan biaya yang diperlukan serta anaknya yang kadang sulit diatur sehingga menimbulkan kemarahan dan rasa tertekan.

Sebagai ibu rumah tangga, wanita selalu disibukkan dengan urusan rumah tangga dan mungkin menimbulkan rasa kebosanan. Dari bahasan tersebut dapat disimpulkan semakin banyak jumlah anak semakin banyak beban, tekanan yang dialami dan semakin cemas pula ibu tersebut. ${ }^{13}$

\section{KESIMPULAN}

Dari hasil penelitian diketahui bahwa tingkat kecemasan wanita klimakterium di Wilayah Kerja Puskesmas Prabumulih Barat dapat disimpulkan, Karakteristik data dari 50 responden mayoritas berpendidikan SD sebanyak 32 orang $(64 \%)$ yang sebagian besar bekerja sebagai petani sebanyak 23 orang (46\%) dengan pendapatan antara $\mathrm{Rp} 650.000$ - Rp 1.000 .000 sebanyak 40 orang (80\%) dan mayoritas memiliki anak lebih dari 3 orang. Tingkat kecemasan dari data mayoritas wanita mengalami kecemasan sedang sebanyak 22 orang (44\%).

\section{DAFTAR PUSTAKA}

1. Andrews, Gilly. 2009. Buku Ajar Kesehatan reproduksi Wanita. Jakarta : EGC.

\section{BKKBN. 2015. Klimakterium dan} Permasalahannya. Jakarta : BKKBN.
3. Manuaba, Ida Bagus Gede. 2008. Ilmu Kebidanan, Penyakit Kandungan dan Keluarga Berencana untuk Pendidikan Bidan. Jakarta : EGC.

4. Kasdu, Dini. 2002. Kiat sehat dan Bahagia di Usia Menopause. Jakarta : Pustaka Pembangunan Swadaya Nusantara.

5. Baziad, Ali. 2003. Menopause dan Andropause. Jakarta : Yayasan Bina Pustaka Sarwaono Prawirohardjo.

6. Indarti, Junita. 2004. Panduan Kesehatan Wanita. Jakarta : Puspa Swara.

7. Rustam, Mochtar. 2005. Sinopsis Obstetri Jilid I. Jakarta : EGC.

8. Notoatmodjo, Soekidjo. 2005. Metodologi Penelitian Kesehatan. Jakarta : PT.Rineka Cipta.

9. Arikunto, Suharsini. 2006. Prosedur Penelitian Suatu Pendekatan Praktik. Jakarta : PT.Rineka Cipta.

10.Hutapea, Ronald. 2005. Sehat dan Ceria di Usia Senja. Jakarta : PT.Rineka Cipta.

11.Proverawati, Atikah. 2010. Menopause dan Sindrome Premenopause. Yogyakarta : Nuha Medika.

12.Wiknjosastro, H. 2005. Ilmu Kandungan. Jakarta : Yayasan Bina Pustaka Sarwono Prawirohardjo.

13.Yatim, F. 2001. Haid Tidak Wajar dan Menopause. Jakarta : Pustaka Populer Obor 
